\title{
IN WHAT DIRECTION IS AGRICULTURAL SPECIALIZATION HEADED IN CENTRAL AND EASTERN EUROPE? (2005-2016)
}

\author{
Csaba Forgacs, CSc. \\ Corvinus University of Budapest
}

\begin{abstract}
The paper deals with the main directions of specialization in Central and Eastern European Countries' (CEECs, EU10) agriculture after the EU's Eastward Enlargement. We analyse and compare growth and productivity advantages of specialized farm types by physical size (in hectare) in EU10 member-states to the EU10/27/15 average based on EUROSTAT data in the period of 2005-2016. We focus on exploring the main directions of specialization using such indicators as the number of specialized farms, land (Utilized Agricultural Area, UAA) and labour (Agricultural Working Unit, AWU) use on the input side, average farm size by land and labour use as well as area-, labour-, and total productivity on the output side.

We conclude that the directions of specialization in farming in EU10 were based on the traditional farm production structure making the latter better able to adjust and take advantages of Common Agricultural Policy. Concerning production growth rate, the three leading specialization types of CEECs' farms were: (i) cattle rearing and fattening, (ii) cereals, oilseed and protein crops and (iii) fruits and citrus fruits. These three specialization types of farms - in the same ranking order - also increased land (UAA) and labour (AWU) use well above the average. Specialized cereals farms and cattle rearing and fattening farms were also ranked in top three by number. Both cereals and fruits specialized farms have leading position in growth rate of land and labour use and also are in top three in growth rate of land area and total farm productivity. Cereals and fruits specialized farms also more than doubled labour productivity during the first decade after the EU's Eastward enlargement but did not rank in the top three in this category.
\end{abstract}

Key words: EU agriculture, specialization, farm size, productivity, CEECs.

JEL code: Q1

\section{Introduction}

Since 2004, there have been significant changes in farm structure both in EU member states and even more so in the EU10, backed by increasing specialization. Within the EU, the dynamics of agricultural development in the old and new member states have been different when considering production structure, specialization and farm size. This paper focuses on the main directions of specialization of farms with UAA (some $2.5 \%$ of specialized farms have no land at all and are not regarded as specialized ones in this study) and shows the extent to which the advantages of specialization have helped the EU10 agriculture catch up over a decade after the EU's Eastward enlargement. We analyse the development of ten types of farm specializations in the EU10 and compare the results both to the EU27/15 average and at the country level in the EU10 using EUROSTAT data for 2005-2016 period.

\section{Literature review}

Over a quarter of a century ago, Tangermann shocked even professionals when claiming that "The structural changes ... going on in Central Europe's agriculture, both on farms and in upstream and downstream sectors, are shaking the foundations of decision-making and economic activities..." (Tangermann, 1994, pp. 379). As real-life data shows, Tangermann had not overestimated the challenge of EU10 farmers at all. Forgacs (2002) pointed out that agriculture output of CEECs declined significantly by $20-60 \%$ (with maximal decline in the Baltics) in 1993-1994 compared to that of years prior to radical reforms in these countries. Some of CEECs have had a very large number of small farms. In 2000, small farms cultivated $80 \%$ or more of the land in Baltic states, Poland, Slovenia and Romania. In contrast, Slovakia, Latvia, the Czech Republic and Hungary followed a different agricultural policy, leading to about three quarter of the agricultural land be used by large farms with 
an average size of 1360 ha, 1135 ha, 998 ha and 960 ha respectively. Small farms have been most affected by the move towards market economies. Within ten years after the EU's Eastward enlargement, 2.8 million mostly small ( $<5$ ha) farms have disappeared in EU10, bringing a second shock for CEECs farmers within two decades.

The role, importance, development and policy aspects of small farms have always got special attention both from researchers and CAP policy makers, both in order to find better ways to help them, and to eliminate weaknesses that CAP had in its policy regarding small farms (EP resolution, 2014; Davidova S,-Bailey A, 2014; Dwyer J, 2014; Davidova S, 2014).

In 2016, some two-thirds of the EU's farms had UAA below 5ha, and close to half of them came from Romania and Poland having decisive agricultural potential in EU10 agriculture. Small farms did their best to find a mixture of crop specialization to increase their chances for survival. Small farms are strong pillars of rural development in the EU and their importance cannot be questioned as they can reduce the risk of rural poverty and generate additional income and food (EUROSTAT. 2018. pp. 18).

The strengthening of the market position of small farms requires efforts from farms themselves, especially with regards to the attitude of being more open to deepening cooperation, as well as looking for new possibilities to become integrated into modern food chains (Csaki C., - Forgacs C., 2008; Gordon M., et al., 2014; Rabinowitz E., 2014). Agricultural policy should pay special attention to Semi-Subsistence Farms (SSFs) in New Member States (Erjavec E., et al., 2014).

"The Central and Eastern European countries (CEECs) viewed CAP subsidies as a major financial benefit of EU membership, and in accession negotiations they fought hard to gain full access to CAP direct payments for their farmers." A hotly debated issue at the Copenhagen summit was the distribution of direct payments to farmers of New Member States (NMS). The discussion led to an agreement to use a gradual phasing-in of direct payments to NMS, reaching full levels over ten years (Baun M., et al. 2009. pp. 271). This ushered in a challenging transitional period for small farms in the EU10 trying to survive the competition with a handicap in subsidies that was only to be eliminated in 2013 or possibly earlier if using national financial sources.

Large and very large farms in the EU28 have focused more on taking advantage of specialization by extending their land to more than $90 \%$ of the total utilized agricultural area in 2013 (EUROSTAT 2018. pp. 20).

Forgacs (2016) showed that small specialized farms achieved higher growth in total productivity backed by intensive labour use than non-specialized farms. In addition, the standard output of specialized farms was higher than that of non-specialized farms in 2005 and 2013 (Forgacs C., 2017). Csaki and Jambor (2018) conducted a study between 1997-2000 and 2013-2016 concerning the convergence of CEECs and Countries of Independent States (CIS). Although they have demonstrated the narrowing of the gap between CEESs and CIS countries in certain areas, their results are unconvincing on the convergence of the CEEs and CIS agriculture production on the whole. Forgacs (2019) analysed the performance of specialized farms by farm types and compared results to those of non-specialized ones. He concluded that among large farms, those that were specialized performed better in the EU10 than their non-specialized counterparts and sustained relatively smaller losses in their labour force. Specialized farms in the EU10 have increased productivity at a higher rate than non-specialized farms (Forgacs C., 2019).

The 2013 Farm Structure Survey drew attention to the fact that while smaller farms (in economic terms) tended to engage in a range of different activities, specialization led to the pursuit of a single 
type of farming. Specialization of larger farms has resulted in an increasing number of specialized horticultures, dairy, pig and cattle rearing farms (EUROSTAT 2016. pp. 19).

The aim of this paper is to give a deep analysis of different aspects of farm specialization of EU10 underlying those indicators where advantages of specialization can be observed over 2005-2016 helping to catch up of the EU10' agriculture.

\section{Methodology}

In an effort to obtain a more sophisticated picture of farms' performance from a specialization point of view in EU10,-15,-27, we used a comparative EUROSTAT data set of 2005-2016, covering the longest period after the EU Eastward enlargement. Indices were used to draw attention to the main structural changes in EU10 against EU15,-27. Key indicators such as farms' labour use (Agricultural Work Unit, AWU), land use (Utilized Agriculture Area, UAA) and production (Standard Output, SO) were analysed. Along with the static analysis, a dynamic approach was also employed to project possible future tendencies. The indicators make it possible to follow productivity development of inputs (land and labour) in EU10 against EU15. Growth of farm size by land, area, labour and total productivity was calculated for cross country analysis on the one hand, and for dynamic analysis of changes in farm structure on the other. Research results of specialized farms in EU10 were compared to that EU15,-27 average. The analysis of growth of observed indicators provides insight into the patterns of farm structure development in 10 specialized farm types ${ }^{1}$ in the EU10.

\section{Research results and discussion}

\section{Increasing share of the number and production (SO) of specialized farms}

After a deep decline, there were still 10.3 million working farms in the EU27 in 2016, compared to the 14.5 million farms of 2005. $56.4 \%$ of the 10.3 million were farms in the EU10, where the overall decline exceeded that of the EU27. In 2016, $49.2 \%$ of farms with UAA were specialized in the EU27, with $44.9 \%$ of these belonging to the EU10, which had four specialized farms in every ten. The decrease in the number of specialized farms with UAA in the EU15 (17.8\%) exceeded that of EU10 (16\%). The survival rate of specialized farms exceeded that of total farms in the EU27 with an even more pronounced difference between the two types of farming in the EU10. An increase in production of specialized farms was a general phenomenon in all EU10 countries with Latvia (230.9 \%), Bulgaria (157.1\%), Lithuania and Slovakia (148-148\%) leading the pack.

Specialization helped the EU10 agriculture slow down the decline in the number of farms, all the while increasing the contribution of specialized farms to total production by $9 \%$ in EU27 and $39.7 \%$ in EU10.

\section{Structural development of specialized farms at the EU10 level}

Concerning the directions of specialization in the EU10, the number of specialized farms in cereal production was the highest among the ten specialized farm types, followed by poultry and dairy farms, both in 2005 and 2016. The share of production of farms specialized in cereal in total specialized farm production increased to $40.3 \%$ in 2016 from $25.2 \%$ in 2005 . Number of vineyards essentially did not change. However, the number of farms specialized in cattle rearing and fattening

${ }^{1}$ The following specialized farm types give the basis for analysis. 1. Specialized in cereals, oilseed and protein crops. 2 . Specialized in horticulture indoor. 3. Specialized in horticulture outdoor. 4. Specialized in vineyards. 5. Specialized in fruit and citrus fruit. 6. Specialized in olive oil. 7. Specialized in dairy farming. 8. Specialized in cattle-rearing and fattening. 9. Specialized in pig production. 10. Specialized in poultry production. 
was rather low in the EU10 in 2005 but has risen by $83.4 \%$ from 2005 to 2016 . Farm specialization has been combined with land concentration. In the EU10, $71.4 \%$ of land cultivated by specialized farms went to cereals specialization in 2016, up from $60.3 \%$ in 2005. Dairy farms lost $5 \%$ of their land over the decade while farms specialized in cattle rearing and fattening used $148.2 \%$ more land in 2016 than they did a decade prior. As far as the labour use is concerned, dairy and cereals specialized farms were the leading ones throughout the decade. In 2005, dairy farms in the EU10 used one third of the labour force of specialized farms, while farms specialized in cereals used $25 \%$ of the farm labour force. In 2016, the extended cereals production surprisingly already used $38.5 \%$ of labour of specialized farms and with corresponding share of dairy farms hovering a bit over $25 \%$.

Table 1

Number and standard output of farms in EU10,-15,-27 (2005, 2016)

\begin{tabular}{|c|c|c|c|c|c|c|c|}
\hline \multirow[b]{2}{*}{ Countries } & \multicolumn{3}{|c|}{2005} & \multicolumn{3}{|c|}{2016} & \multirow[b]{2}{*}{$\begin{array}{c}\text { Share of spec } \\
\text { in total } \\
2016 / 2005\end{array}$} \\
\hline & $\begin{array}{c}\text { Total } \\
\text { farms }\end{array}$ & $\begin{array}{c}\text { Spec } \\
\text { farms } \\
\text { with UAA } \\
\text { total }\end{array}$ & $\begin{array}{l}\text { Share of } \\
\text { spec in } \\
\text { total } \\
\text { farms }\end{array}$ & $\begin{array}{c}\text { Total } \\
\text { farms }\end{array}$ & $\begin{array}{c}\text { Spec } \\
\text { farms } \\
\text { with UAA } \\
\text { total }\end{array}$ & $\begin{array}{l}\text { Share of } \\
\text { spec in } \\
\text { total } \\
\text { farms }\end{array}$ & \\
\hline \multicolumn{7}{|c|}{ Number (Million) } & $\%$ \\
\hline EU27 & 14.5 & 6.1 & 42.4 & 10.3 & 5.1 & 49.2 & 115.9 \\
\hline EU10 & 8.6 & 2.7 & 31.9 & 5.8 & 2.3 & 39.2 & 122.8 \\
\hline EU15 & 5.8 & 3.4 & 57.9 & 4.5 & 2.8 & 62.3 & 107.6 \\
\hline \multirow[t]{2}{*}{ EU10/15 } & 1467 & 80.8 & 55.1 & 130.5 & 82.0 & 62.9 & 114.2 \\
\hline & \multicolumn{6}{|c|}{ Standard Output (Million EURO) } & $\%$ \\
\hline EU27 & 286345 & 176339 & 61.6 & 362083 & 243077 & 67.1 & 109.0 \\
\hline EU10 & 42262 & 17510 & 41.4 & 59907 & 34667 & 57.9 & 139.7 \\
\hline EU15 & 243267 & 158374 & 65.1 & 301461 & 207969 & 69.0 & 106.0 \\
\hline EU10/15 & 17.4 & 11.1 & 63.6 & 19.9 & 16.7 & 83.9 & 131.8 \\
\hline
\end{tabular}

Source: Based on EUROSTAT data

The production value of specialized farms in the EU10 amounted to EUR 17.5 billion in 2005 that went up to EUR 34.7 billion (an increase of $98 \%$ ) in 2016 well above the rate of increase in the EU15 (31 \%) (Table 1). In 2005, $26.7 \%$ of the production of specialized farms in the EU10 came from dairy farms, exceeding the corresponding figure in the EU15 (25.2\%), meanwhile in case of cereals that figure was $25.2 \%$ in the EU10 and only $8.3 \%$ in the EU15. In the EU10, the share of dairy farms production decreased from $26.7 \%$ in 2005 to $22.3 \%$ in 2016, but that of cereals farms showed an upswing to $40.3 \%$ from $25.2 \%$ in 2005. In the EU10, the top 3 leading specialized farms (dairy, cereals and poultry) gave two thirds of the total production of specialized farms in 2005, with their contribution increasing further to $77.7 \%$ in 2016. The corresponding averages in the EU15 were $42.8 \%$ and $49.3 \%$, respectively.

Farms by physical size are bigger in EU15 than EU10. In 2005, the average farm size in the EU27/10/15 was 11.9 ha, 5.5 ha and 21.4 ha respectively. The average farm size of specialized farms was larger when compared to non-specialized farms in general (EU27/10/15). The ratio of average farm size by land between EU15 and EU10 was higher than that of specialized farms. In the EU15, the average size of specialized farms was smaller than the overall average farm size by some $10 \%$ both in 2005 and 2016. In the EU10, the picture was the opposite, the average farm size of specialized farms exceeded that of total farms both in 2005 and 2016 and, the ratio between the two increased over time. 


\section{Productivity indicators of specialized farms in the EU10}

Production value of specialized farms on average exceeded that of non-specialized farms in the EU15 and in the EU10. In 2005, average production of specialized farms (SO/spec farm) in the EU10 amounted to EUR 6403 , only $13.7 \%$ of that of the EU15, indicating that the total productivity level of EU10 specialized farms is well behind that of EU15. The two types of specialized farms in the EU10 where this figure was the largest were cereals (23.8\%) and cattle rearing and fattening $(23.2 \%)$. The average production of specialized farms in the EU10 increased by $137.4 \%$ over the ensuing decade reaching $20.3 \%$ of that of EU15 in 2016. 8 out of 10 specialization farm types of the EU10 showed higher growth when compared to the EU15 average. Per farm production value caught up more dynamic in poultry, cereals and fruits specialized farms (growth by $218.7 \%, 175.6 \%$, and $172.9 \%)$.

In 2005, the gap between average area productivity (SO/UAA) of specialized farms in the EU10 and EU15 was narrower than the gap between total farm productivity in the EU10 and EU15. Specialized farms in the EU10 have made significant progress in catching up since 2005, increased area productivity reaching $44.5 \%$ of that of the EU15 average in 2016. In 2005, area productivity of cereals $(63.8 \%)$, cattle rearing and fattening $(52.1 \%)$ and poultry farms (52\%) of the EU10 already exceeded $50 \%$ of EU15 average. By 2016, due to high growth (apart from olive farms) area productivity was more than $50 \%$ of that of the EU15 average in already 4 out of 9 specialized farm types. Poultry and cereals specialized farms have the highest EU10/EU15 ratio at $81.1 \%$ and $74.2 \%$ respectively, while this figure in case of pigs and cattle rearing and fattening specialized farms was $65.3 \%$ and $58.9 \%$ respectively. We conclude that when considered as contributors to the EU10 agriculture, specialized farms have achieved remarkable growth in area productivity, pushing the EU10 average figure closer to that of the EU15. Farms specializing in pigs almost tripled production value per hectare, poultry farms doubled and cereals farms close to doubled their production value per hectare between 2005 and 2016. Progress notwithstanding, specialized farms in the EU15 on average produced EUR 2982 per hectare in 2016 compared to the EU10 average of EUR 1326 per hectare.

Concerning labour productivity (SO/AWU), the difference between the EU10 and EU15 farms is quite big on the whole. In 2005 (and 2016 respectively), the average EU10 labour productivity was $14.8 \%$ (20.9\% resp.) of the EU15's corresponding measure, although when restricted to specialized farms, the figure improved to $18.9 \%$ (25.8 \% resp.). One working unit (AWU) produced a production value EUR 9,220 in the EU10, while the same figure was EUR 48,848 in the EU15 in 2005. However, labour productivity of specialized farms in the EU10 rose by $108.1 \%$ exceeding the growth rate in the EU15 and reaching $25.8 \%$ of the EU15 average in 2016. As we have already pointed out, specialized farms in the EU10 saw a smaller decline in their labour force between 2005 and 2016 that did non-specialized farms (5.3\% against $34.3 \%$ ). This could easily have led to worsening labour productivity measures. The fact that labour productivity actually improved over this period on specialized farms is due to their ability of improve the effective use of labour, reflecting a better adjustment to production needs.

\section{Main characteristics of farms by farm specialization types}

In the EU10, the production of specialized farms doubled between 2005 and 2016, meanwhile total production increased by only $41.8 \%$. The most important specialization types of farming by production in the EU10 are cereals, dairy and poultry farms with a $66.7 \%$ share of the total 
specialized farm production in 2005 , which rose to $77.7 \%$ in 2016 , with decreasing contributions from dairy and increasing contribution from cereals. These three types of specialization constituted three quarters of the specialized farms in 2005 and slightly more in 2016. Within these three specializations, the number of cereal farms grew significantly, while the number of poultry and dairy farms each declined by about $25 \%$. As to land use, the share of cereals and dairy farms amounts to $85.2 \%$ in 2005 and $88.2 \%$ in 2016 . The three specialization types of farms play an important role in labour use as well. In 2005, $71.1 \%$ of specialized farm labour worked on cereals, poultry and dairy farms, a figure that increased to $74.4 \%$ in 2016. In the EU10, farms found specialization in fruits and cattle rearing and fattening more profitable compared to previous period and started to increase production above the average.

Concerning farm size by land, radical changes have taken place in the EU10. In 2005, the average size of specialized farms in the EU10 was 6.8 ha, where cattle rearing and fattening, cereals and dairy farms were well above the average. In 2016, the average size of cattle rearing and fattening (22.1 ha) and cereals (18.7 ha) were the largest, while the highest growth (162.6\%) took place in outdoor horticulture in EU10. Farms specialized in poultry and fruits also significantly increased land area (by $60.6 \%$ and $55.5 \%$ respectively). Specialized farms in the EU10 accommodated an average of 0.7 AWU labour in 2005, ranging from 0.4 ha in poultry to 1.7 in indoor horticulture. Growth dynamics were significant in dairy farms (growth by $110.8 \%$ ), while fruits, cereals and outdoor horticulture also demonstrated above average growth. We note however, that the difference between the lowest and highest levels increased (0.4 and 2.8 AWU). In 2016, apart from olives, the average size of labour used by specialized farms in EU10 already exceeded that of the EU15 in dairy (by $34.1 \%$ ), cattle rearing and fattening (by $17.4 \%$ ) and cereals (by $14.8 \%$ ). Still, the size of specialized farms by land in the EU15 was more than double that of the EU10, with vineyard sizes six times bigger than their EU10 counterparts.

\section{Development of specialization in EU10 by countries}

According to data, it is obvious that all EU10 countries went through farm structure development by giving priority to specialization in order to adjust to the Common Agricultural Policy. In all EU10 countries, except Slovenia where level of specialization was above EU10 average in 2005, the share of specialized farms increased from $31.9 \%$ in 2005 to $39.2 \%$ in 2016. The highest growth of specialization took place in Lithuania and Latvia (76.7 \% and $76.2 \%)$ followed by Bulgaria $(66.6 \%)$ and the Czech Republic (33.3\%). A key feature of farm structure development in the EU10 was the increased number of farms specialized in cereals production and cattle rearing and fattening in general, and an enormous growth in number of poultry farms in the Baltic countries ${ }^{1}$. The production of specialized farms doubled in the EU10, but tripled in Latvia, and more than doubled in Bulgaria, Lithuania and Poland. In the EU10, more than half of the production came from specialized farms in 2016. The growth of the share of specialized farms in total farms was the highest in Lithuania and Romania (60.6 \% and 59.1\%). In 2016, in seven of the EU10 countries specialized cereals farms led production, while in Estonia and Poland dairy farms did, and in Slovenia cattle rearing and fattening was most productive.

The average size (by area) of specialized farms of the EU10 increased by $67.4 \%$ from 2005 to 2016 with big differences between EU10 countries (cereal farm sizes, for example, ranged between 10.1 ha (Slovenia) and 167 ha (Czech Republic)). In five out of the EU10 countries average cereals

${ }^{1}$ Lithuania and Latvia saw a $400 \%$ increase, and Estonia witnessed a $40 \%$ increase in the number of poultry farms. 
specialized farm size exceeded that of the EU15 average. In three of these five countries the average cereal farm size was at least 140 ha compared to the EU15 average of 46.9 ha.

The relative size of average production per farm between EU10 and EU15 is highest for cereals $(29.6 \%)$, cattle rearing and fattening (29.0\%) and fruits farms $(25.7 \%)$. In all other types of farm specialization this figure is close to $20 \%$ or less, indicating that there is still a big difference in average production of specialized farms between EU10 and EU15 in 2016. The growth rate of SO/farm, SO/UAA and SO/AWU of specialized farms exceeded that of non-specialized farms in the EU10 but it was opposite in the EU15 (Table 2).

Table 2

Dynamics of economic indicators in EU10 and EU15, \% (2005-2016)

\begin{tabular}{|l|c|c|c|c|c|c|}
\hline \multirow{2}{*}{ Farms } & \multicolumn{5}{|c|}{ Dynamics of SO/ (FARM, UAA, AWU) } \\
in EU10,-15 in 2005-2016, \% (2005=100) \\
\cline { 2 - 7 } & $\mathbf{2 0 0 5}$ & $\mathbf{2 0 0 7}$ & $\mathbf{2 0 1 0}$ & $\mathbf{2 0 1 3}$ & $\mathbf{2 0 1 6}$ \\
\hline & \multicolumn{5}{|c|}{ S0/ farm } \\
\hline EU10 NON-SPECIALIZED FARMS* & 100.0 & 101.7 & 120.5 & 146.6 & 168.2 \\
\hline EU10 SPECIALIZED FARMS with UAA & 100.0 & 116.2 & 157.9 & 200.5 & 237.4 \\
\hline EU15 NON-SPECIALIZED FARMS* & 100.0 & 103.1 & 125.9 & 150.8 & 161.0 \\
\hline EU15 SPECIALIZED FARMS with UAA & 100.0 & 103.4 & 113.5 & 145.7 & 159.8 \\
\hline & \multicolumn{5}{|c|}{ S0/UAA } \\
\hline EU10 NON-SPECIALIZED FARMS* & 100.0 & 97.0 & 101.9 & 119.6 & 133.8 \\
\hline EU10 SPECIALIZED FARMS with UAA & 100.0 & 99.3 & 108.7 & 123.8 & 140.7 \\
\hline EU15 NON-SPECIALIZED FARMS* & 100.0 & 98.1 & 102.5 & 112.2 & 122.4 \\
\hline EU15 SPECIALIZED FARMS with UAA & 100.0 & 99.3 & 105.0 & 111.2 & 122.0 \\
\hline & \multicolumn{5}{|c|}{ S0/AWU } \\
\hline EU10 NON-SPECIALIZED FARMS* & 100.0 & 109.2 & 136.6 & 160.6 & 192.3 \\
\hline EU10 SPECIALIZED FARMS with UAA & 100.0 & 111.9 & 155.6 & 178.8 & 208.1 \\
\hline EU15 NON-SPECIALIZED FARMS* & 100.0 & 99.3 & 125.9 & 141.2 & 153.4 \\
\hline EU15 SPECIALIZED FARMS with UAA & 100.0 & 101.0 & 121.2 & 138.0 & 152.5 \\
\hline
\end{tabular}

*Including specialized farms without UAA

Source: Based on EUROSTAT data

Looking at area productivity (SO/UAA), the specialized farms of the EU10 achieved a relatively higher ratio of $44.5 \%$ against EU15 average in 2016. In five types of specialized farms, apart from olives, this ratio is already above $50 \%$. The highest figure was $81.1 \%$ in poultry and $74.2 \%$ in cereal specialized farms. The EU10/EU15 average ratio in labour productivity (SO/AWU) was only $25.8 \%$ in 2016. The highest ratio goes to indoor horticulture specialized farms with $46.7 \%$, while in 6 farm types the EU10 average does not reach $26 \%$ of the EU15 average. In cereal specialized farms there are 4 CEECs with labour productivity above EU15 average, in dairy farms there are only 2, in fruits and outdoor horticulture only one each. It is a real challenge for the EU10 countries to speed up area productivity in order to become more competitive.

\section{Conclusions}

1) Extending specialization has been an effective path for EU10 agriculture production development for catching up leading to an overall growth in production of $98 \%$ between 2005 and 2016.

2) Among all specializations in the EU10, cereals, dairy and poultry specialized farms had the highest share in production $(40.3 \%, 22.3 \%$ and $15.1 \%$ respectively) in 2016 , while the three fastest growing specialized farms were cattle rearing and fattening $(69.5 \%)$, cereals (59.8 \%) and fruits $(11.9 \%)$. 
3) In 2016, in 7 out of the EU10 countries cereals specialized farms were leading production. In Estonia and Poland dairy farms, while in Slovenia cattle rearing and fattening specialized farms had the highest share.

4) An increase of production of the specialized farms was a general phenomenon in all EU10 countries with Latvia (230.9\%), Bulgaria (157.1\%), Lithuania and Slovakia (148-148\%) in the front of the pack.

5) In 7 out of EU10 countries cattle rearing and fattening specialized farms reached the fastest growth in production, in Estonia fruits farms, and in the Czech Republic and Slovenia cereals farms taking the lead.

6) The outstanding growth of production of specialized farms in EU10 was fuelled by a high increase of area productivity and an even higher one in labour productivity against non-specialized farms.

\section{Suggestion}

Specialization should continue to characterize the EU10 agriculture in its effort to catch up with the EU15 countries. In particular, specializing in cereals, cattle rearing and fattening, dairy, fruits and poultry farming coupled with increased productivity should serve as main drivers.

\section{Bibliography}

1. Agriculture, Forestry and Fishery in Statistics 2018 Edition (2018). Retrieved: https://ec.europa.eu/eurostat/documents/3217494/9455154/KS-FK-18-001-EN-N.pdf/a9ddd7db-c40c48c9-8ed5-a8a90f4faa3f. Access:12.03.2020.

2. Baun, M., Kouba, K., \& Marek, D. (2009). Evaluating the Effects of the EU Common Agriculture Policy in a New Member State: The Case of the Czech Republic. Journal of Contemporary European Studies, 17(2), pp. 271-292.

3. CAP Reform. (2003). Retrieved: http://www.oecd.org/tad/32039793.pdf . Access:12.03.2018.

4. Csaki, C., - Jambor, A. (2018). Konvergencia vagy divergencia? Merre tart Kelet-Kozep-Europa es a FAK mezogazdasaga? (Convergence or Divergence? Where to Heading Agriculture of CEECs and CIS?). Budapest. Kozgazdasagi Szemle. LXV. evf., 2018. October. pp. 1048-1066.

5. Csaki, C.,-Forgacs, C. (2008). Smallholders and Changing Markets: Observations on Regional Level. Society and Economy. Vol. 30, number 1. June. pp. 5-28.

6. Davidova, S. (2014). Small and Semi-Subsistence Farms in the EU: Significance and Development Path. EuroChoices. Vol. 13, number 1. pp. 5-8.

7. Davidova, S., and Bailey, A. (2014). Roles of Small and Semi-subsistence Farms in the EU. EuroChoices. Vol. 13, number 1. pp. 10-13.

8. DG Agriculture (2016). Research for Agri Committee - Structural Change in EU Farming: How Can the CAP Support 21st Century European Model of Agriculture? Retrieved: http://www.europarl.europa.eu/RegData/etudes/STUD/2016/573428/IPOL_STU(2016)573428_EN.pdf Access: 12.03 .2018$.

9. Dwyer, J. (2014). CAP Reform Proposals for Small and Semi-Subsistence Farms. EuroChoices. Vol. 13. number 1. pp. 31-34.

10. Erjavec, E., - Falkowski, J.,- Juvancic, L. (2014). Structural Change and Agricultural Policy for SSFs: A View from the 2004 NMSs. EuroChoices. Vol. 13, number 1. pp. 41-44.

11.EP Resolution (2014). Motion for A European Parliament Resolution on the Future of Small Agricultural Holdings. Retrieved: http://www.europarl.europa.eu/sides/getDoc.do?type=REPORT\&mode=XML\&reference=A7-20140029\&language $=\mathrm{EN} \#$ title2. Access: 14.03 .2018 .

12. EUROSTAT (2016). Small and Large Farms in the EU - Statistics from the Farm Structure Survey. pp.19. Retrieved: http://ec.europa.eu/eurostat/statisticsexplained/index.php/Small_and_large_farms_in_the_EU__statistics_from_the_farm_structure_survey. Access:12.03.2016.

13. EUROSTAT (2018). Small and Large Farms in the EU - Statistics from the Farm Structure Survey. pp. 18 Retrieved: https://ec.europa.eu/eurostat/statistics-explained/pdfscache/54736.pdf. Access: 11.03.2020.

14. Forgacs, C. (2002). The Challenge of Integrating CEECs' Agriculture into the EU. Presidential Address. Xth Congress of EAAE. Zaragoza. August.

15. Forgacs, C. (2016). Is Specialization a Way for Small Farms to Adjust in CEE (EU-10). Economic Science for Rural Development 2016. Jelgava. April 21-22. Proceedings. No 42. pp. 221-227.

16. Forgacs, C. (2017). Growth and Productivity Advantages of Specialized Farms in Central and Eastern European Countries in 2005-2013 (2017). Acta Aeoconomia. 2017.1. ISSN 1644-0757. ISSN 2450-4602. pp. 13-23. 
Proceedings of the 2020 International Conference "ECONOMIC SCIENCE FOR RURAL DEVELOPMENT" No 53

Jelgava, LLU ESAF, 12-15 May 2020, pp. 48-56

DOI: $10.22616 / E S R D .2020 .53 .005$

17. Forgacs, C. (2019). Main Drivers of Central and Eastern European Countries' Agriculture in 2005-2013: Specialization and Land Concentration. Proceedings of the 2019 International Conference "ECONOMIC SCIENCE FOR RURAL DEVELOPMENT" No 50 Jelgava, LLU ESAF, 9-10 May 2019, pp. $320-327$ DOI: 10.22616/ESRD.2019.040

18. Gordon, M., - Salvioni, C., and Hubbard, C. (2014). Semi-subsistence Farms and Alternative Food Supply Chains. EuroChoices. Vol. 13, number 1. pp. 15-18.

19. Rabinowitz, E. (2014). Farm size: Why Should we care? EuroChoices. Vol. 13. number 1. pp. 28-29.

20. Tangermann, S. (1994). West looks East. European Review of Agricultural Economics 21. pp. 375-392. 